TITLE:

\title{
Fallback Foods of Red Leaf Monkeys (Presbytis rubicunda) in Danum Valley, Borneo
}

$\operatorname{AUTHOR}(S):$

Hanya, Goro; Bernard, Henry

\section{CITATION:}

Hanya, Goro ... [et al]. Fallback Foods of Red Leaf Monkeys (Presbytis rubicunda) in Danum Valley, Borneo. International Journal of Primatology 2012, 33(2): 322-337

ISSUE DATE:

2012-04

URL:

http://hdl.handle.net/2433/154842

\section{RIGHT:}

The final publication is available at www.springerlink.com; この論文は 著者最終稿です。内容が印刷版と異なることがありますので、引用の 際には出版社版をご確認ご利用ください。This is the Accepted Author Manuscript. Please cite only the published version. 
1 Fallback foods of red leaf monkeys (Presbytis rubicunda) in Danum Valley,

2 Borneo

3

4 Goro Hanya * and Henry Bernard †

5

6 * Primate Research Institute, Kyoto University, Inuyama, Japan

7 Institute for Tropical Biology and Conservation, Universiti Malaysia Sabah,

8 Kota Kinabalu, Sabah, Malaysia

9

10 Correspondence to: G. Hanya: Primate Research Institute, Kyoto University,

11 Kanrin 41-2, Inuyama, Aichi, 484-8506 Japan. E-mail: hanya@pri.kyoto-u.ac.jp,

12 Tel: +81-568-63-0542, Fax: +81-568-63-0564

13

14 Running title: Diet of red leaf monkey

15

16 
17 Abstract Animals in Southeast Asia must cope with long periods of fruit

18 scarcity of unpredictable duration between irregular mast fruiting events.

19 Long-term data is necessary to examine the effect of mast fruiting on diet, and

20 particularly on the selection of fallback foods during periods of fruit scarcity. No

21 such data is available for colobine monkeys, which may consume substantial amounts of fruits and seeds when available. We studied the diet of red leaf monkeys (Presbytis rubicunda, Colobinae) in Danum Valley, Sabah, northern

24 Borneo, using 25 months of behavioral observation, phenology and vegetation surveys and chemical analysis to compare leaves eaten with non-food leaves.

The monkeys spent $46 \%$ of their feeding time on young leaves, $38 \%$ on seeds, $12 \%$ on whole fruits, $2.0 \%$ on flowers, $1.0 \%$ on bark, and $1.2 \%$ on pith. They spent more time feeding on seeds and whole fruit when fruit availability was high and fed on young leaves of Spatholobus macropterus (liana, Leguminosae) as fallback foods. This species was by far the most important food, constituting $27.9 \%$ of the total feeding time, and the feeding time on this species negatively correlated with fruit availability. Consumed leaves contained more protein than non-consumed leaves, and variation in time spent feeding on different leaves was explained by their abundance. These results suggest that red leaf monkeys show essentially the same response to the supra-annual increase in fruit availability as sympatric monogastric primates, increasing their seed and whole-fruit consumption. However, they depended more on young leaves, in particular Spatholobus macropterus, as fallback foods during fruit-scarce periods than did gibbons or orangutans. Their selection of fallback food appeared to be due to both nutrition and abundance.

41 Key words: diet; fallback foods; functional response; general flowering, 
42

43

44

45

46

47

48

49

50

51

52

53

54

55

56

57

58

59

60

61

62

63

64

65

\section{Spatholobus macropterus}

\section{Introduction}

Seasonal environmental changes can impose serious food shortages or physical stress on animals. For example, animals in Southeast Asia must cope with extreme super-annual seasonality in flowering and fruiting. In lowland dipterocarp forests in the Malay Peninsula, Borneo and Sumatra, many plants come into flower simultaneously for a few weeks to a few months and subsequently set fruit massively (mast fruiting); however, these species of plants rarely flower outside these general flowering events (Sakai 2002; Wich and van Schaik 2000). General flowering events occur at unpredictable intervals every 2-6 years (Sakai 2002). Variation also occurs spatially. For example, mast fruiting may occur in only one region, or may occur on the entire Malay Peninsula (Yasuda et al. 1999). Between mast fruiting events animals must survive a long flower- or fruit-scarce period of unpredictable duration. The larger inter-annual variability in fruiting in SE Asia than in other regions (van Schaik and Pfannes 2005) is thought to have strong effects on community structure and may be responsible for the low species diversity observed in this region (Reed and Bidner 2004).

Animals in SE Asia cope with this strong seasonality in various ways, including both numerical and functional responses. Numerical response occurs both by migration and reproduction, and thus immediate response is possible for volant and/or fast-reproducing animals, such as giant honey bees (Apis dorsata) (Itioka et al. 2001) and thrips (Ashton et al. 1988). However, a functional response is often the only option for non-volant, slow-reproducing animals. The 
order primates is a particularly interesting taxon in this context, since primates are among the few large animals that can use the canopy, where most plant reproduction takes place. Most primates do not increase their number in response to the fluctuations of fruit availability, although orangutans may show resource-tracking migration (Buij et al. 2002). Instead primates rely on the resources available in their current habitat, meaning that fallback foods play an indispensable role in their survival in seasonal habitats. The two species of orangutan (Pongo abelii and $P$. pygmaeus) offer the best examples of primate functional response to mast fruiting. Their diet consists mostly of fruits during mast fruiting, but they fall-back on young leaves and bark during non-fruiting seasons (Kanamori et al. 2010; Knott 1998; Wich et al. 2006). Furthermore, orangutans accumulate fat during the mast fruiting period and metabolize it when the fruit availability decreases (Knott 1998). However, data for other species are scant, as long-term data are necessary to reveal the effect of mast 81 fruiting. of strong super-annual seasonality in fruit abundance on primate populations. Despite the classical view that primates of the subfamily Colobinae are obligate folivores (Clutton-Brock 1977), colobines are now known to consume substantial amounts of fruits and seeds, with the average fruit- and seed-feeding time of 24 colobine species reaching 31\% (Kirkpatrick 1999). Although they sometimes feed on fleshy fruits, they typically consume only unripe ones, as acidic fruits may disrupt the forestomach fermenting system (Lambert 1998). primary lowland dipterocarp forest of Danum Valley, Sabah, Malaysian Borneo, 
92 for 25 months. Red leaf monkeys can be classified as folivorous/gramnivorous;

93 their feeding time over 13 months at Sepilok, Sabah, was composed of $36 \%$

94 young leaves, $30 \%$ seeds, $19 \%$ whole fruits, $11 \%$ flowers and other minor foods

95 (Davies 1991). We aimed to (1) describe dietary changes of this species in

96 response to seasonal fluctuations in fruit and young leaf availability, (2) identify

97 the fallback foods they feed on during the fruit scarcity, i.e. foods for which

98 consumption was negatively correlated with the availability of preferred foods

99 (Marshall et al. 2009), and (3) elucidate the chemical and distributional

100 properties that explain the differences of consumed vs. non-consumed and

101 frequently vs. rarely consumed young leaves.

102

\section{Methods}

104 Study site

105 The study site is a primary forest around the Danum Valley Field Centre $\left(4^{\circ} 57^{\prime} \mathrm{N}\right.$, $106117^{\circ} 48^{\prime} \mathrm{E}, 300 \mathrm{~m}$ above sea level) within the Danum Valley Conservation Area 107 (438 km²) located in eastern Sabah, northern Borneo. During 2007 and 2008, 108 rainfall was $3,115 \mathrm{~mm} /$ year and mean daily maximum, minimum and mean 109 temperatures were $31.4^{\circ} \mathrm{C}, 22.5^{\circ} \mathrm{C}$ and $26.9^{\circ} \mathrm{C}$, respectively (Fig. 1; data 110 provided by the Danum Valley Field Centre). The forest is predominantly 111 composed of lowland dipterocarp trees (Newbery et al. 1999). Canopy height is 112 approximately $50 \mathrm{~m}$, with emergent trees more than $70 \mathrm{~m}$.

114 Behavioral observation

115 We observed one habituated group of red leaf monkeys with 8-12 individuals 116 from around 6:00 until 16:00, 5-10 days per month. We recorded their behavior 
117 by scan sampling: every ten minutes we recorded the activity (feeding, moving,

118 resting) of all visible individuals, except for dependent infants. When they were

119 feeding, we recorded the food category and collected samples for later

120 identification. We collected data for 25 months from December 2006 to

121 December 2008. Total observation time was 1141 hours, and the monthly

122 observation time was 16-87 hours (mean: 46 hours). Observation time per day

123 was $7.22 \pm$ SD 2.27 hours. Sometimes we could not find monkeys in the early

124 morning or terminated observation before 16:00 due to heavy rain. Therefore,

125 observation time in the periods of 6:00-7:00 (46 h), 14:00-15:00 (88 h), and

126 15:00-16:00 (79 h) was less than for other hours of the day (104-149 h).

127 However, this bias in observation time is unlikely to have influenced the main

128 results because it was similar across months

129

130 Phenology

131 We used data on monthly tree phenology accumulated by the Danum Valley

132 Field Centre since July 2004, using the same plot set as Norayati (2001) and the

133 same protocol as the census conducted from August 1997 until December 2000

134 (Wong et al. 2005). They monitored flushing, flowering and fruiting activities of

$135511-533$ identified trees of $\geq 10 \mathrm{~cm} \mathrm{DBH}$ every month. Plots were situated in

136 primary forest, including the home range of the study group. The monitored area

137 consisted of five transects, each $20 \times 100 \mathrm{~m}$, placed every $400 \mathrm{~m}$ along the $2 \mathrm{~km}$ 138 trail.

139

140 Vegetation

141 We took data on the botanical composition of the forest from Lingenfelder (2005). 
142 The vegetation plot was different from that used to study phenology but covered

143 a larger area. We used data for a 4-ha plot in the study site, for which all trees

$144 \geq 10 \mathrm{~cm} \mathrm{DBH}$ were identified to species and their DBH measured. Because these

145 data did not include lianas, we added data on Spatholobus macropterus

146 (Leguminosae), an important food source for red leaf monkeys at this site. We

147 set a transect along a circular trail which covers most of the home range (ca 16

$148 \mathrm{ha})$, of $4 \mathrm{~m} \times 1.2 \mathrm{~km}$ and recorded the presence/absence of this liana for all trees

149 along the transect.

150

151 Chemical analysis

152 We compared the chemical properties of young leaves consumed and not

153 consumed by the red leaf monkeys. We sampled young leaves of all species that

154 constituted at least $1 \%$ of the feeding time and the top 20 species in abundance

155 (basal area) in the study area of the vegetation survey (Lingenfelder 2005;

156 Newbery et al. 1996). We included young leaves of 7 consumed species and 16

157 non-consumed species in analyses.

158 For each tree species consumed, we took young leaf samples from at

159 least four individual trees from which the monkeys had been feeding. We

160 sampled at least 20 leaves for each species. We kept the leaves in plastic bags

161 and took them to the Field Centre where we dried them immediately at $60^{\circ} \mathrm{C}$ for

16260 hours using an oven. Afterwards, we stored the leaves in plastic bags and

163 took them to the laboratory at the Primate Research Institute, Kyoto University,

164 where we dried them again at $60^{\circ} \mathrm{C}$ for 48 hours using a vacuum incubator. After

165 weighing, we milled leaves, put them into a plastic tube and kept them in a

166 desiccator. 
We determined crude protein using the Kjeldahl procedure for total

168 nitrogen and multiplying by 6.25. Since fiber-bound nitrogen is not taken into

169 account, metabolizable protein may have been lower (Rothman et al. 2008). We

170 measured crude lipid as diethyl-ether extract by the Soxhlet method (Soxhlet

171 1879). We determined crude ash by ashing at $550^{\circ} \mathrm{C}$. We estimated neutral

172 detergent fibre (NDF) following methods in van Soest (1991). We extracted

173 condensed tannin with 50\% methanol and determined its presence / absence

174 using the butanol-HCl method (Porter 1989). We used presence / absence since

175 it is difficult to estimate the concentration of condensed tannin with this method

176 (Rautio et al. 2007). We used the ratio of weight of the constituents to the total

177 dry weight for analysis of crude protein, crude lipid, NDF and crude ash.

178

179 Data analysis

180 Due to the high canopy and dense vegetation, the number of individuals we 181 observed in each scan was low (mean: 1.95, SD: 1.12). To avoid over-

182 representation of highly visible behaviors or foods, we divided the number of 183 individuals engaged in each activity (in case of feeding, number of individuals

184 feeding on a particular food item) for each scan by the total number of individuals 185 observed in the scan (Agetsuma 1995; Harrison 1985; Maruhashi 1981). We

186 summed this value for each month for each food item and calculated the 187 proportion this represented of the total feeding record. Patterns in the seasonal 188 variations in the diet evaluated with and without this correction were similar, and 189 the results for the effect of phenology on diet did not change. We examined the effect of the proportion of fruiting and flushing trees in 191 the phenology survey on the proportion of feeding time of the particular food 
192

193

194

195

196

197

198

199

200

201

202

203

204

205

206

207

208

209

210

211

212

213

214

215

216

category (or species) using a generalized linear model (GLM). We used data for each month as the unit of analysis $(\mathrm{N}=25)$. Since the data were significantly nonnormality (Kolmogorov-Smirnov test, $\mathrm{p}<0.05$ ), we applied the quasi family and calculated quasi AIC (Akaike's Information Criterion) using the 'QAIC' function of the package 'MuMIn' in R 2.13.2 (Burnham and Anderson 2002). We combined fruit and seed feeding because we expected these two categories of foods to respond in a similar way to fruit availability. We used only the food species in the phenology census for the analyses, although we also present data on all food species. The variance inflation factor (VIF) was 1.05, which was less than the cut-off value (5), so collinearity among independent factors did not affect the results. We choose the model with the smallest AIC among all possible combinations of independent factors, including the null model.

We examined young leaf food selection at two different levels using GLMs. We examined the following six independent factors: crude protein, NDF, crude ash, crude lipid, presence/absence of condensed tannin, and abundance (number of stems/4 ha, using the vegetation data). First, we examined the effect of these properties on whether the monkeys fed on a species (1) or not (0) (binomial distribution). Then we examined the effects on the proportion of feeding time for food leaves. We started from the full model and then decreased the number of independent factors until the AIC did not decrease any further (backward stepwise). The maximum variance inflation factor (VIF) was 2.35, which was less than the cut-off value (5), so collinearity among independent factors did not affect the results.

We used R 2.13.2. (C) The R Foundation for Statistical Computing) for all the statistical analyses. We set the alpha level at $\mathrm{P}<0.05$. 


\section{Results}

219 Phenology

220 There was one clear peak of fruiting during the 25 month study, from May to

221 October 2007 (Fig. 2a). This was the largest peak in the period August 1997 to

222 December 2000 (Wong et al. 2005). During this high fruiting period, 2.8-6.7\% of 223 trees bore fruits while only $0-1.9 \%$ of trees did so out of this period. The number 224 of flushing trees also fluctuated considerably (Fig. 2b).

225

226 Overall diet

227 Red leaf monkeys fed on young leaves (46\% of feeding time), seeds (38\%), 228 whole fruits (12\%), flowers (2.0\%), bark (1.0\%), pith (1.2\%) and other foods 229 (unspecified foods and mature leaf, 0.2\%). The monkeys ate all whole fruits 230 unripe and masticated the seeds. They consumed plant parts from at least 122 231 different species (identified at least to genus level) belonging to 50 different 232 families, 103 of which we identified to species (Table 1). The main food families 233 were Leguminosae (10 species), Lauraceae (10), Euphorbiaceae (8), Meliaceae

234 (8) and Sapindaceae (7). Young leaves of Spatholobus macropterus 235 (Leguminosae, liana) were by far the most important foods, which constituted $23627.9 \%$ of the total feeding time, followed by the seeds of Chionanthus pluriflorus 237 (Oleaceae, 4.2\%) and Nothaphoebe umbelliflora (Lauraceae, 4.1\%; Table 2). 238

239 Seasonal variation

240 Red leaf monkeys increased seed and fruit consumption and decreased 241 young leaf consumption when fruit availability was high (Fig. 4). The best-fit 
model predicting fruit+seed consumption included only a positive effect of the percentage of trees fruiting (Table 2a). The best-fit model predicting young leaf consumption also included only the percentage of trees fruiting but with a negative effect (Table $2 b$ ). The percentage of trees flushing was not included in these best-fit models (Fig. 5). The model that included only the percentage of flushing trees was the second-best fit to explain the fruit+seed consumption and young leaf consumption, which had $\triangle \mathrm{QAIC}$ values (difference from the QAIC of the best-fit model) of 0.40 and 0.33 , respectively. The model that included both the percentage of flushing and fruiting trees was the third-best fit, and it had a $\triangle$ QAIC value of 1.98 , for fruit+seed consumption as well as for young leaf consumption.

When fruit availability decreased red leaf monkeys consumed young leaves of S. macropterus. Feeding time on young leaves on S. macropterus (27.9\%) was much longer than for the second most important leaf species (Ziziphus angustifolia, 1.5\%, Table 3) and S. macropterus was consumed in each of the 25 study months. Feeding time on the young leaves of $S$. macropterus was significantly negatively correlated with the percentage of fruiting trees $(\mathrm{N}=25$, $r=-0.49, P=0.012$, Pearson's correlation), but the sum of the feeding time of the other species was not $(r=-0.27 ; P=0.17)$. Feeding time on young leaves of the second- and third-most consumed species, which constituted more than $1 \%$ of the total feeding time, also did not correlate with the percentage of fruiting trees

263 (Xanthophyllum affine: $r=-0.15, P=0.48$; Ziziphus angustifolia: $r=0.06, P=0.77$ ).

Young leaf selection

266 Red leaf monkeys chose young leaves which contained more crude protein than 
267 leaves of common species as food, and consumed the most abundant species $S$.

268

269

270

271

272

273

274

275

276

277

278

279

280

281

282

283

284

285

286

287

288

289

290

Discussion

291 Response to fruiting seasonality other factors.

macropterus most frequently. The best-fit model for the difference between consumed and non-consumed leaves included only a positive effect of crude protein content (Table 4a). The second- and third-best fit models included crude ash or lipid in addition to crude protein, and these had $\triangle \mathrm{AIC}=1.97$ or 2.00 , respectively. A high protein content increased the likelihood that a leaf species was selected as food. The protein content of young S. macropterus leaves was the third highest (20.5\%) and 1.5 times higher than the mean value of the 23 species examined (13.8\%). The difference between consumed and non-consumed species was not significant for NDF ( $t=1.72, P=0.10)$, crude ash $(t=1.18, P=0.25)$, crude lipid $(t=1.04, P=0.31)$, and abundance $(t=0.59, P=0.56)$, but significant for crude protein ( $t=4.78, P=0.0001$; Fig. 6).

GLM model selection did not identify the most significant factors explaining the variation in feeding time among food species because the best-fit model included 5 independent factors (Table 4b). The second-best-fit model had an extremely larger value of $\triangle \mathrm{AIC}(28.9)$. However, we found a significant correlation with feeding time for abundance $(\mathrm{N}=7, \mathrm{r}=0.99, \mathrm{P}<0.0001)$ but not for the other factors (NDF: $r=0.52, P=0.23$; crude protein: $r=0.16, P=0.72$; crude ash: $r=0.63, P=0.12$; crude lipid: $r=0.01, P=0.98)$. In addition, there was no difference in feeding time between tannin-free and tannin-bound species $(t=1.33$, $P=0.24)$. This suggests that the effect of abundance was more important than

Response to fruiting seasonality 
292 Red leaf monkeys increased whole fruit and seed consumption in response to 293 increased fruit availability, and increased young leaf consumption when fruit 294 availability was low. Qualitatively, these findings are essentially the same 295 response as that shown by monogastric Bornean orangutans and Müller's 296 gibbons (Hylobates muelleri) (Kanamori et al. 2010; Vogel et al. 2009), which live 297 sympatrically with red leaf monkeys in various parts of Borneo, and indicate that 298 fruits and seeds are preferred foods for all of these primates. However, the 299 responses of red leaf monkeys and sympatric apes differ quantitatively, although caution is required here because the studies were not conducted at the same time and in the same place. Orangutans in Danum Valley decrease their fruit-feeding time to less than $50 \%$ only infrequently (7 of 27 months (Kanamori et al. 2010) and fruit feeding time for gibbons at Tuanan was more than $50 \%$ even at the lowest fruit availability (Vogel et al. 2009). Red leaf monkeys were apparently less dependent on fruits and seeds. Fruit and seed feeding time was less than $50 \%$ for the majority of the study period (16 out of 25 months). During the period of fruit scarcity, red leaf monkeys shifted their diet from fruits and seeds to leaves, while gibbons continue to search for fruits, such as figs. Orangutans are intermediate to these two species.

311 Fallback foods

312 Red leaf monkeys in Danum Valley used the young leaves of Spatholobus 313 macropterus as a fallback food, as consumption of these leaves was negatively 314 correlated with the availability of preferred foods (Marshall et al. 2009). Young 315 leaves of other species were not fallback foods, as their feeding time was not 316 related to fruit availability. 
318 foods (Lambert 2007), and the fallback strategies of red-leaf monkeys and

319 gibbons seem to rely on 'low-' and 'high-quality' foods, respectively. Dependence

320 on 'low-quality' foods is often associated with digestive and dental adaptations

321 that allow the extraction of sufficient energy from the low-quality foods (Marshall

322 et al. 2009), including the foregut fermentation of red leaf monkeys (Lambert

323 1998). Unlike brachiating gibbons, who can move quickly in the canopy (Vogel et

324 al. 2009), it is difficult for red leaf monkeys to effectively search for rare

325 resources, such as fruiting fig trees, making abundance a particularly important

326 factor in finding fallback foods in their habitat.

Red leaf monkeys appear to depend on young leaves of $S$.

macropterus as fallback food for two reasons: high protein content and high abundance. There is a universal trend among colobus monkeys to prefer leaves with more protein (Chapman and Chapman 2002; Kar-Gupta and Kumar 1994; Yeager et al. 1997), and this includes red leaf monkeys in Sepilok (Davies et al. 1988). Condensed tannins or other phenolic compounds do not usually affect food selection of colobus monkeys (Chapman and Chapman 2002; Kool 1992; Maisels et al. 1994; Mowry et al. 1996), in contrast to monogastric primates such as macaques (Hanya et al. 2007). S. macropterus differed from other protein-rich leaves by its extreme abundance. The stem density of $S$. macropterus (302/ha) was much higher than those of other leaf food species (0.25-34/ha). Animals can reduce searching cost by eating abundant species 339 (Hanya et al. 2007). This is particularly important for red leaf monkeys, which do 340 not have special adaptations for quick movement through the canopy like 341 gibbons (Vogel et al. 2009). Interestingly, the young leaf of S. macropterus is 
also one of the important fallback foods for sympatric orangutans, constituting more than $20 \%$ of their feeding time during periods of fruit scarcity (Kanamori et al. 2010). In response to decreased fruit availability, orangutans decrease their feeding time on fruits to less than $20 \%$ and shift to eating young leaves and bark (Kanamori et al. 2010). They also cannot move as quickly in the canopy as gibbons (Vogel et al. 2009) and may select young leaves of S. macropterus as fallback foods for a similar reason to that of red leaf monkeys. However, red leaf monkeys in Sepilok consume young leaves of another species of Spatholobus (latistipulus), but no single species constituted most of the feeding time (Davies et al. 1988), unlike S. macropterus in the Danum Valley. The selection of fallback food may be strongly affected by the local flora, and it is not consistent within species.

Marshall and Wrangham (2007) defined fallback foods as food that is low-quality but abundant. Our finding that the leaves of this species contain more protein than common species seems to contradict their definition superficially. However, Marshall and Wrangham (2007) used the term 'low-quality' only when compared with preferred food items. If we suppose that the quality of young leaves, including S. macropterus, is lower than that of fruits and seeds, and red leaf monkeys chose $S$. macropterus among those 'low-quality' foods, our finding and their definition do not contradict. However, leaves and seeds, which are the two most important foods for Colobinae (Kirkpatrick 1999), have different nutritional and distribution properties (Janson and Chapman 1999), and so it is difficult to judge which is lower in quality than the other. In fact, another species of colobine (Trachypithecus francoisi) shows a positive correlation between the availability and feeding time of young leaves, but this is not the case for fruits 
367 and seeds (Zhou et al. 2009). A comprehensive comparison is necessary

368 between these two types of foods in order to evaluate the value as food for 369 colobines.

370

371 In conclusion, we found that the red leaf monkey increased seed and whole-fruit 372 consumption in response to the supra-annual increase in fruit availability, which

373 is the essentially the same response as that found in sympatric monogastric

374 primates. However, they depended more on young leaves, in particular

375 Spatholobus macropterus, as fallback foods than did gibbons or orangutans.

376 This species appeared to be eaten so often due to its high protein content and

377 extreme abundance.

378 


\section{Acknowledgements}

380 This study would not have been possible without the hard work of our field assistants, Syamsudin Jail, Sharry bin Mustah, Saharudin Idos, Unding Jami,

382 Sallehudin Jail and Rayner Jupili. We are greatly indebted to the staff of the

383 Danum Valley Field Centre and our colleagues there for their hospitality and help,

384 in particular Jimmy Omar, Mike Bernadus, Glen Reynolds, Tomoko Kanamori, 385 Noko Kuze and Siew Te Wong. Constructive comments by Drs. Joanna Setchell, 386 Oliver Shülke and an anonymous reviewer were really helpful in improving the 387 manuscript. The Economy Planning Unit of Malaysia and the State of Sabah and 388 the Danum Valley Management Committee of Yayasan Sabah permitted our 389 study. This study was financed by the JSPS Core-to-Core Program (HOPE), the 390 MEXT Grant-in-Aid for JSPS Overseas Fellows, Grant-in-Aid for Young 391 Scientists (No. 20770195 and No. 22687002) to GH, Primate Society of Japan, 392 the 21st Century COE Program (A14) and Global COE Program "Formation of a 393 Strategic Base for Biodiversity and Evolutionary Research: from Genome to 394 Ecosystem." 


\section{References}

397 Agetsuma, N. (1995). Foraging strategies of Yakushima macaques (Macaca

398 fuscata yakui). International Journal of Primatology, 16, 595-609.

399 Ashton, P. S., Givnish T. J. \& Appanah S. (1988). Staggered flowering in the

400 Dipterocarpaceae: new insights into floral induction and the evolution of mast

401 fruiting in the aseasonal tropics. American Naturalist, 132, 44-66.

402 Buij, R., Wich S. A., Lubis A. H. \& Sterck E. H. M. (2002). Seasonal movements

403 in the Sumatran orangutan (Pongo pygmaeus abelii) and consequences for

404 conservation. Biological Conservation, 107, 83-87.

405 Burnham, K. P. \& Anderson D. R. (2002). Model Selection and Multi-model

406 Inference. 2nd Edition. Springer, New York.

407 Chapman, C. A. \& Chapman L. J. (2002). Foraging challenges of red colobus

408 monkeys: influence of nutrients and secondary compounds. Comparative

409 Biochemistry And Physiology A-Molecular And Integrative Physiology, 133,

$410 \quad 861-875$.

411 Clutton-Brock, T. H. (1977). Primate Ecology: Studies of Feeding and Ranging

412 Behaviour in Lemurs, Monkeys and Apes. Academic Press, Brighton.

413 Davies, A. G., Bennett E. L. \& Waterman P. G. (1988). Food selection by 2

414 southeast Asian colobine monkeys (Presbytis rubicunda and Presbytis

415 melalophos) in relation to plant chemistry. Biological Journal of the Linnean

416 Society, 34, 33-56.

417 Davies, G. (1991). Seed-eating by red leaf monkeys (Presbytis rubicunda) in

418 dipterocarp forest of northern Borneo. International Journal of Primatology, 12, 419 119-144.

420 Hanya, G., Kiyono M., Takafumi H., Tsujino R. \& Agetsuma N. (2007). Mature 
421 leaf selection of Japanese macaques: effects of availability and chemical content.

422 Journal of Zoology, 273, 140-147.

423 Harrison, M. J. S. (1985). Time budget of the green monkey, Cercopithecus

424 sabaeus: some optimal strategies. International Journal of Primatology, 6, $425 \quad 351-376$.

426 Itioka, T., Inoue T., Kaliang H., Kato M., Nagamitsu T., Momose K., Sakai S.,

427 Yumoto T., Mohamad S. U., Hamid A. A. \& Yamane S. (2001). Six-year 428 population fluctuation of the giant honey bee Apis dorsata (Hymenoptera : 429 Apidae) in a tropical lowland dipterocarp forest in Sarawak. Annals of the 430 Entomological Society of America, 94, 545-549.

431 Janson, C. \& Chapman C. (1999). Resources and primate community structure. 432 In J. Fleagle, C. Janson \& K. Reed (eds), Primate Communities (pp. 237-267). 433 Cambridge: Cambridge Univ Press.

434 Kanamori, T., Kuze N., Bernard H., Malim T. P. \& Kohshima S. (2010). Feeding 435 ecology of Bornean orangutans (Pongo pygmaeus morio) in Danum Valley, 436 Sabah, Malaysia: A 3-year record including two mast fruitings. American Journal 437 of Primatology, 72, 820-840.

438 Kar-Gupta, K. \& Kumar A. (1994). Leaf chemistry and food selection by common 439 langurs (Presbytis entellus) in Rajaji National Park, Uttar Pradesh, India.

440 International Journal of Primatology, 15, 75-93.

441 Kirkpatrick, R. C. (1999). Colobine diet and social organization. In P. Dolhinow \&

442 A. Fuentes (eds), The Nonhuman Primates (pp. 93-105). Mountain View:

443 Mayfield Publishing Company.

444 Knott, C. D. (1998). Changes in orangutan caloric intake, energy balance, and

445 ketones in response to fluctuating fruit availability. International Journal of 
Primatology, 19, 1061-1079.

447 Kool, K. M. (1992). Food selection by the silver leaf monkey, Trachypithecus

448 auratus sondaicus, in relation to plant chemistry. Oecologia, 90, 527-533.

449 Lambert, J. E. (1998). Primate digestion: Interactions among anatomy,

450 physiology, and feeding ecology. Evolutionary Anthropology, 7, 8-20.

451 Lambert, J. E. (2007). Seasonality, fallback strategies, and natural selection: a

452 chimpanzee and Cercopithecoid model for interpreting the evolution of the

453 hominin diet. In P. S. Ungar (ed. Evolution of the human diet: the known, the 454 unknown, and the unknowable (pp. 324-343). Oxford: Oxford University Press.

455 Lingenfelder, M. (2005) Rain forest dynamics and response to drought in a 456 Bornean primary lowland dipterocarp forest (PhD thesis) pp. 179. University of 457 Bern, Bern.

458 Maisels, F., Gauthier-Hion A. \& Gautier J. P. (1994). Diets of 2 sympatric 459 colobines in Zaire: more evidence on seed-eating in forests on poor soils. 460 International Journal of Primatology, 15, 681-701.

461 Marshall, A. J. \& Wrangham R. W. (2007). Evolutionary consequences of 462 fallback foods. International Journal of Primatology, 28, 1218-1235.

463 Marshall, A. J., Boyko C. M., Feilen K. L., Boyko R. H. \& Leighton M. (2009).

464 Defining fallback foods and assessing their importance in primate ecology and 465 evolution. American Journal of Physical Anthropology, 140, 603-614.

466 Maruhashi, T. (1981). Activity patterns of a troop of Japanese monkeys (Macaca 467 fuscata yakui) on Yakushima Island, Japan. Primates, 22, 1-14.

468 Mowry, C. B., Decker B. S. \& Shure D. J. (1996). The role of phytochemistry in 469 dietary choices of Tana River red colobus monkeys (Procolobus badius 470 rufomitratus). International Journal of Primatology, 17, 63-84. 
471 Newbery, D. M., Campbell E. J. F., Proctor J. \& Still M. J. (1996). Primary lowland 472 dipterocarp forest at Danum Valley, Sabah, Malaysia. Species composition and 473 patterns in the understorey. Vegetatio, 122, 193-220.

474 Newbery, D. M., Kennedy D. N., Petol G. H., Madani L. \& Ridsdale C. E. (1999).

475 Primary forest dynamics in lowland dipterocarp forest at Danum Valley, Sabah, 476 Malaysia, and the role of the understorey. Philosophical Transactions of the 477 Royal Society B-Biological Sciences, 354, 1763-1782.

478 Norhayati, A. (2001) Frugivores and fruit production in primary and logged 479 tropical rainforests (PhD thesis). In: Faculty of Science and Technology pp. 269. 480 Universiti Kebangsaan Malaysia, Bangi, Malaysia.

481 Porter, L. J. (1989). Tannins. In P. M. Dey \& J. B. Harborne (eds), Methods in 482 Plant Biochemistry, vol.1. Plant Phenolics (pp. 389-419). London: Academic 483 Press.

484 Rautio, P., Bergvall U. A., Karonen M. \& Salminen J. P. (2007). Bitter problems in 485 ecological feeding experiments: Commercial tannin preparations and common 486 methods for tannin quantifications. Biochemical Systematics And Ecology, 35, $487 \quad 257-262$.

488 Reed, K. E. \& Bidner L. R. (2004). Primate communities: past, present, and 489 possible future. Yearbook of Physical Anthropology, 47, 2-39.

490 Rothman, J. M., Chapman C. A. \& Pell A. N. (2008). Fiber-bound nitrogen in 491 gorilla diets: Implications for estimating dietary protein intake of primates.

492 American Journal of Primatology, 70, 690-694.

493 Sakai, S. (2002). General flowering in lowland mixed dipterocarp forests of 494 South-east Asia. Biological Journal of the Linnean Society, 75, 233-247. 495 Soxhlet, F. (1879). Die gewichtsanalytische Bestimmung des Milchfettes. 
Polytechnisches J, 232, 461-465.

497 van Schaik, C. P. \& Pfannes K. (2005). Tropical climates and phenology: a

498 primate perspective. In D. K. Brockman \& C. P. van Schaik (eds), Seasonality in

499 Primates: Studies of Living and Extinct Human and Non-Human Primates (pp.

500 23-54). Cambridge: Cambridge University Press.

501 van Soest, P. J., Robertson J. B. \& Lewis B. A. (1991). Methods for dietary fiber,

502 neutral detergent fiber, and nonstarch polysaccharides in relation to animal

503 nutrition. Journal of Dairy Science, 74, 3583-3597.

504 Vogel, E. R., Haag L., Mitra-Setia T., van Schaik C. P. \& Dominy N. J. (2009).

505 Foraging and ranging behavior during a fallback episode: Hylobates albibarbis

506 and Pongo pygmaeus wurmbii compared. American Journal of Physical

507 Anthropology, 140, 716-726.

508 Wich, S. A. \& van Schaik C. P. (2000). The impact of El Niño on mast fruiting in

509 Sumatra and elsewhere in Malesia. Journal of Tropical Ecology, 16, 563-577.

510 Wich, S. A., Utami-Atmoko S. S., Setia T. M., Djoyosudharmo S. \& Geurts M. L.

511 (2006). Dietary and energetic responses of Pongo abelii to fruit availability

512 fluctuations. International Journal of Primatology, 27, 1535-1550.

513 Wong, S. T., Servheen C., Ambu L. \& Norhayati A. (2005). Impacts of fruit

514 production cycles on Malayan sun bears and bearded pigs in lowland tropical

515 forest of Sabah, Malaysian Borneo. Journal of Tropical Ecology, 21, 627-639.

516 Yasuda, M., Matsumoto J., Osada N., Ichikawa S., Kachi N., Tani M., Okuda T.,

517 Furukawa A., Nik A. R. \& Manokaran N. (1999). The mechanism of general

518 flowering in Dipterocarpaceae in the Malay Peninsula. Journal of Tropical

519 Ecology, 15, 437-449.

520 Yeager, C. P., Silver S. C. \& Dierenfeld E. S. (1997). Mineral and phytochemical 
521 influences on foliage selection by the proboscis monkey (Nasalis larvatus).

522 American Journal of Primatology, 41, 117-128.

523 Zhou, Q. H., Huang Z. H., Wei X. S., Wei F. W. \& Huang C. M. (2009). Factors

524 influencing interannual and intersite variability in the diet of Trachypithecus

525 francoisi. International Journal of Primatology, 30, 583-599.

526

527

528 
Diet of red leaf monkey Hanya and Bernard

Table 1. Number of species consumed by the red leaf monkeys

\begin{tabular}{ccccc}
\hline \multirow{2}{*}{ Food category } & $\begin{array}{c}\text { No. Species } \\
\text { Total }\end{array}$ & $\begin{array}{c}\text { No. Species } \\
\text { Tree }\end{array}$ & $\begin{array}{c}\text { No. Species } \\
\text { Liana }\end{array}$ & $\begin{array}{c}\text { No. Species } \\
\text { Epiphyte }\end{array}$ \\
\hline Young leaf & 68 & 50 & 14 & 4 \\
Seed & 54 & 40 & 14 & 0 \\
Whole fruit & 27 & 21 & 6 & 0 \\
529 & 11 & 8 & 3 & 0 \\
Flower, flower bud & 4 & 2 & 2 & 0 \\
Pith & 5 & 5 & 0 & 0 \\
Bark & 1 & 1 & 0 & 0 \\
\cline { 2 - 5 }
\end{tabular}

530 
Table 2. Best-fit generalized linear models for the effect of phenology on the seasonal variations of diet

a. Feeding time of fruits and seeds

$\mathrm{QAIC}=6.88, \mathrm{R}^{\wedge} 2=0.35, \mathrm{P}=0.00043$

\begin{tabular}{lcccc}
\hline & Coefficient & $\mathrm{SE}$ & $\mathrm{t}$ & $\mathrm{p}$ \\
\hline (Intercept) & 0.35 & 0.06 & 6.22 & 0.000 \\
\%Fruiting tree & 6.90 & 1.96 & 3.52 & 0.002 \\
\hline
\end{tabular}

b. Feeding time of young leaves

$\mathrm{QAIC}=6.78, \mathrm{R}^{\wedge} 2=0.33, \mathrm{P}=0.00073$

\begin{tabular}{lcccc}
\hline & Coefficient & $\mathrm{SE}$ & $\mathrm{t}$ & $\mathrm{p}$ \\
\hline (Intercept) & 0.59 & 0.05 & 11.20 & 0.000 \\
\%Fruiting tree & -6.21 & 1.84 & -3.38 & 0.003 \\
\hline
\end{tabular}

$531 \%$ \%ruiting tree: Percentage of trees bearing food fruits or seeds 


\section{Diet of red leaf monkey \\ Hanya and Bernard}

Table 3. Feeding time of main food species and the months when they were consumed

\begin{tabular}{|c|c|c|c|c|c|c|c|c|c|c|c|c|c|c|c|c|c|c|c|c|c|c|c|}
\hline Caterory & Sneciec & Family & Time & 200620 & 07 & & & & & & & & & & & $\overline{58}$ & & & & & & & \\
\hline valegory & species & raminy & lime & $\mathrm{D} \mathrm{J}$ & $\mathrm{F}$ & M & $A$ & $\mathrm{MJ}$ & $\mathrm{J}$ & & & & $\mathrm{N}$ & $\mathrm{D}$ & $\mathrm{J}$ & $F$ & $\mathrm{MA}$ & $\mathrm{M}$ & J & & S & $\mathrm{ON}$ & V D \\
\hline Young leaf & Spatholobus macropterus & Leguminosae & $27.9 \%$ & ** & * & * & * & * * & * & * & * & * & * & * & * & * & ${ }^{*} *$ & * & * & * & * & * * & * \\
\hline Seed & Chionanthus pluriflorus & Oleaceae & $4.2 \%$ & & & * & * & * & & & & & & & & * & * * & & & & & * & \\
\hline Seed & Nothaphoebe umbelliflora & Lauraceae & $4.1 \%$ & * * & * & * & * & & & * & & & & & & * & * & & * & * & * & * & \\
\hline Fruit & Ficus xylophylla & Moraceae & $2.7 \%$ & & & * & & & & & & & & & * & & & & & * & & & \\
\hline Seed & Syzygium racemosum & Myrtaceae & $2.6 \%$ & * & * & & & & & & & & & & & & & & & & & & \\
\hline Seed & Lithocarpus gracilis & Fagaceae & $2.5 \%$ & & & & & & & & * & * & * & & & & & & & & & & \\
\hline Seed & Paranephelium xestophyllum & Sapindaceae & $2.4 \%$ & & & & & & & * & * & * & & & & & & & * & * & * & & \\
\hline Fruit & Ficus trichocarpa & Moraceae & $2.1 \%$ & * & & & & & * & & & & & & & & & & & & & * & * \\
\hline Seed & Spatholobus macropterus & Leguminosae & $2.1 \%$ & & & & & * & * & & * & * & * & & & & & & & & & & \\
\hline Seed & Bauhinia sp1 & Leguminosae & $2.1 \%$ & & * & * & & & & & & & & & * & * & * & & & & & & \\
\hline Seed & Chisocheton sarawakensis & Meliaceae & $1.8 \%$ & & & & & & & & & & * & & & & & * & * & & * & * * & * \\
\hline Seed & Litsea elliptibacea & Lauraceae & $1.7 \%$ & & * & * & * & * * & & & & & & & & & & & & & & * * & * * \\
\hline Young leaf & Ziziphus angustifolia & Rhamnaceae & $1.5 \%$ & & * & * & * & * & & * & & * & * & * & * & * & * * & * & & & & * * & * \\
\hline Seed & Ardisia elliptica & Myrsinaceae & $1.4 \%$ & & & & & & & & & & & & & & & * & * & & & & \\
\hline Seed & Nephelium cuspidatum & Sapindaceae & $1.2 \%$ & & & & & & & & * & * & ^ & * & & & & & & & & & \\
\hline Young leaf & Xanthophyllum affine & Polygalaceae & $1.1 \%$ & * & & * & & * & & & & & & & & & * & & & & * & * * & * \\
\hline Fruit & Bridelia pinangensis & Euphorbiaceae & $1.1 \%$ & * & & & & & & & & & & & & & & & & & & & \\
\hline Seed & Syzygium rivulare & Myrtaceae & $1.0 \%$ & & & & & & & & * & & & & & & & & & & & & \\
\hline
\end{tabular}

* indicates that the food was eaten in that month.

533 Only foods which constituted at least $1 \%$ of the feeding time during the study period was included. 
Table 4. Best-fit models for the effect of leaf chemistry and abundance on young leaf sel€

a. Food (1) vs. non-food (0)

$A I C=17.6, R^{\wedge} 2=0.54, P=0.0001$

\begin{tabular}{lcccc}
\hline & Coefficient & SE & $t$ & $\mathrm{p}$ \\
\hline (Intercept) & -9.24 & 3.80 & -2.43 & 0.015 \\
Crude protein & 56.20 & 23.93 & 2.35 & 0.019 \\
\hline
\end{tabular}

b. Feeding time of young leaves

$A I C=-79.3, R^{\wedge} 2=0.99, P<0.00001$

\begin{tabular}{ccccc}
\hline & Coefficient & SE & $\mathrm{t}$ & $\mathrm{p}$ \\
\hline (Intercept) & -0.16 & 0.02 & -8.23 & 0.077 \\
NDF & -0.82 & 0.05 & -16.55 & 0.04 \\
Crude ash & 7.99 & 0.58 & 13.75 & 0.046 \\
Crude lipid & 2.29 & 0.22 & 10.31 & 0.062 \\
Condensed tannin & 0.07 & 0.01 & 9.75 & 0.065 \\
Abundance & 0.00 & 0.00 & 18.57 & 0.034 \\
\hline
\end{tabular}


537 Legends for figures

538 Fig. 1. Climate data from the Danum Valley Field Centre for December 2006-December 2008.

540 Fig. 2. Fruiting (a) and flushing (b) phenology between July 2004 and December 2008. Values are percentage of total trees in the sample plot bearing fruit at a given time. Closed diamonds: all trees; open squares: red leaf monkey food species only.

544 Fig. 3. Seasonal changes in the diet composition of red leaf monkeys; values are percent of monthly feeding time spent on each food category.

Fig. 4. Relationships between fruiting phenology (proportion of trees bearing fruits in the phenology plot) and time spent feeding on (a) fruits and seeds and (b) young leaves.

549 Fig. 5. Relationships between flushing phenology (proportion of trees having young leaves in the phenology plot) and time spent feeding on (a) fruits and seeds and (b) young leaves.

552 Fig. 6. Comparison of chemical properties and abundance between consumed and non-consumed young leaves (mean+SD) Values are proportion of dry weight for (a)-(d). Consumed species include Spatholobus macropterus (Leguminosae; $27.9 \%$ of feeding time), Ziziphus angustifolia (Rhamnaceae; 1.5\%), Xanthophyllum affine (Polygalaceae; 1.1\%), Ryparosa hullettii (Flacourtiaceae; 0.5\%), Parashorea malaanonan (Dipterocarpaceae; 0.2\%), Koompassia excelsa (Leguminosae; 0.1\%), and Nothaphoebe umbelliflora (Lauraceae; 0.1\%). 


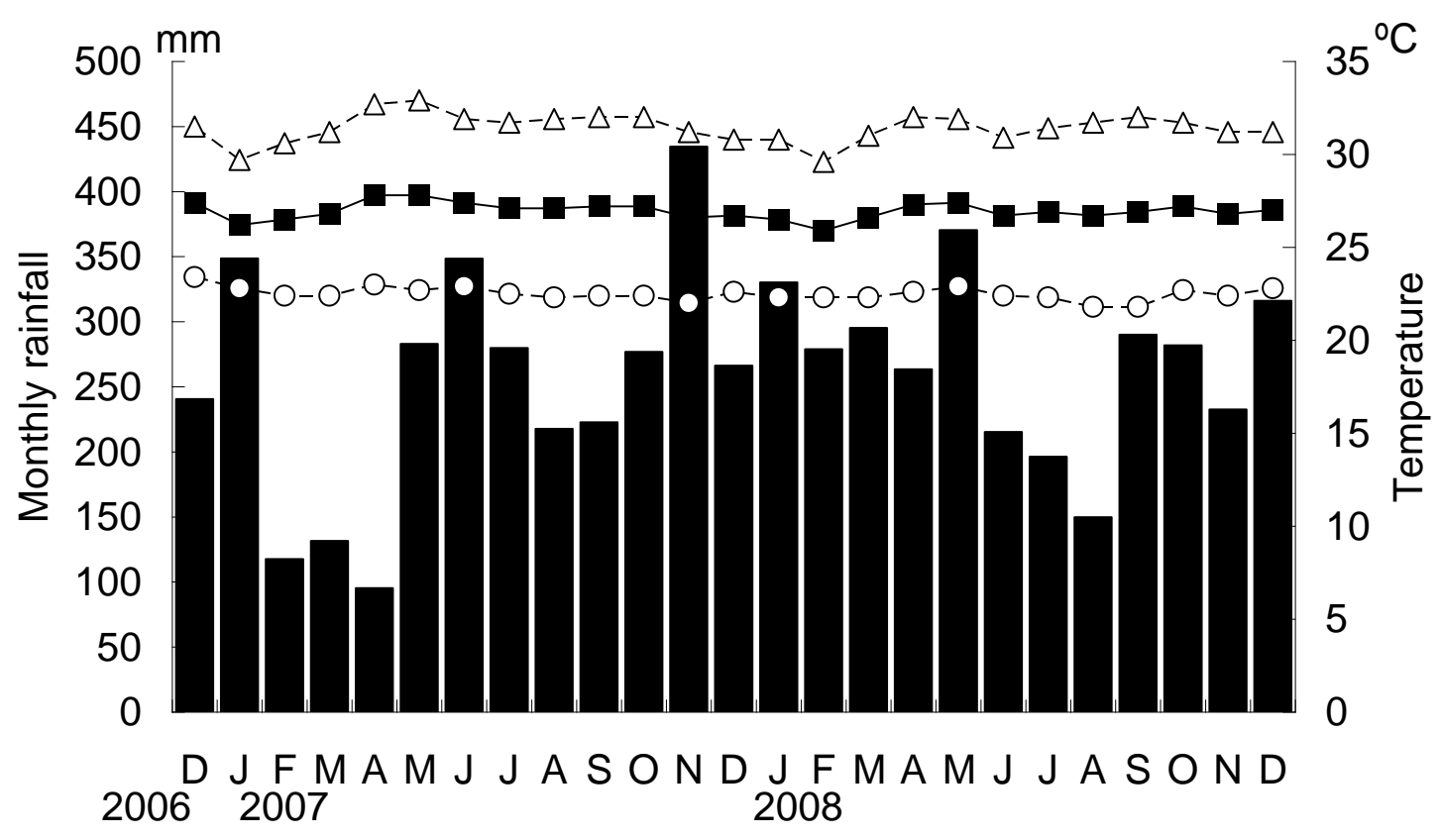

$562 \quad$ Fig. 1 


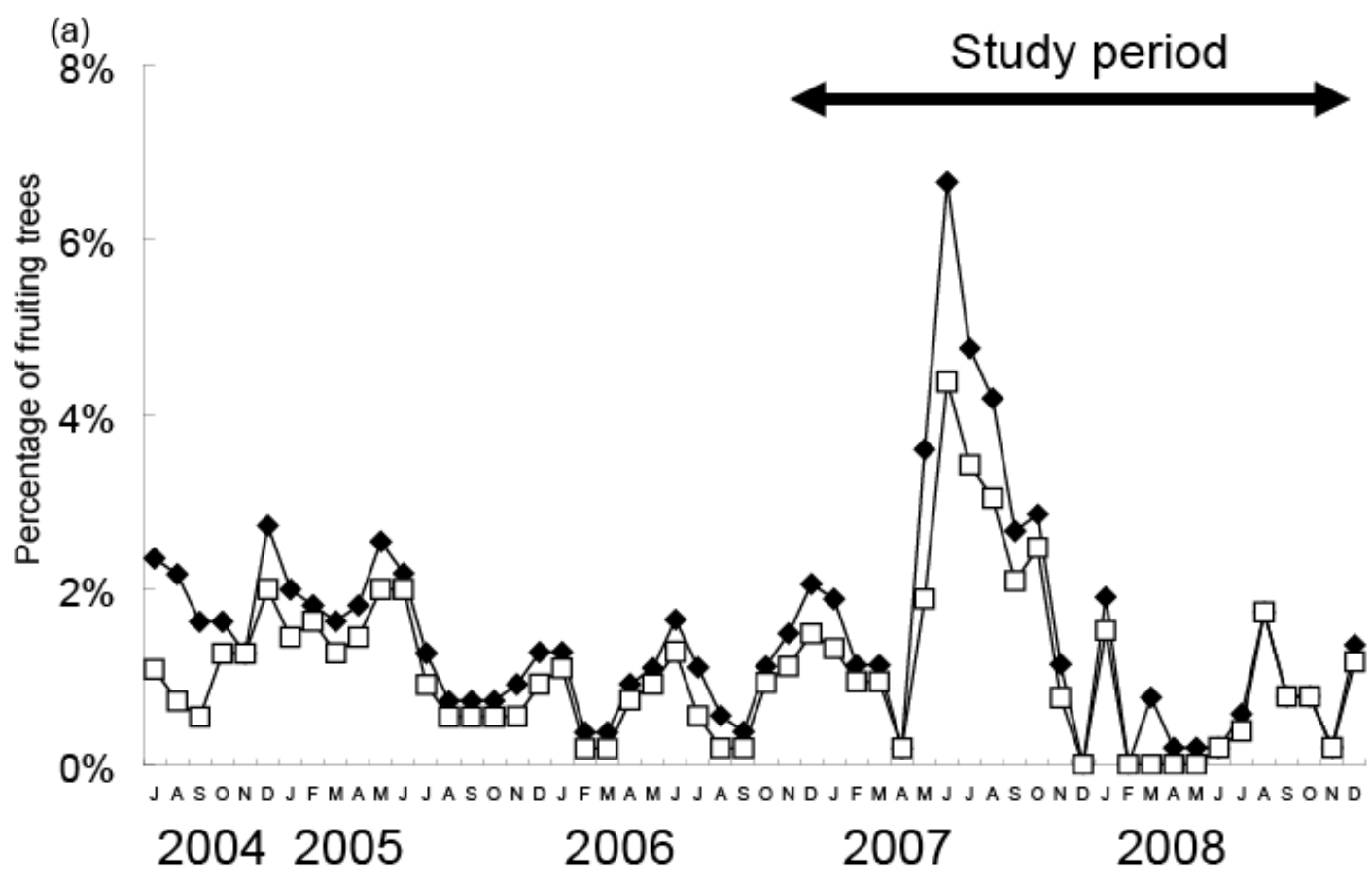

(b)

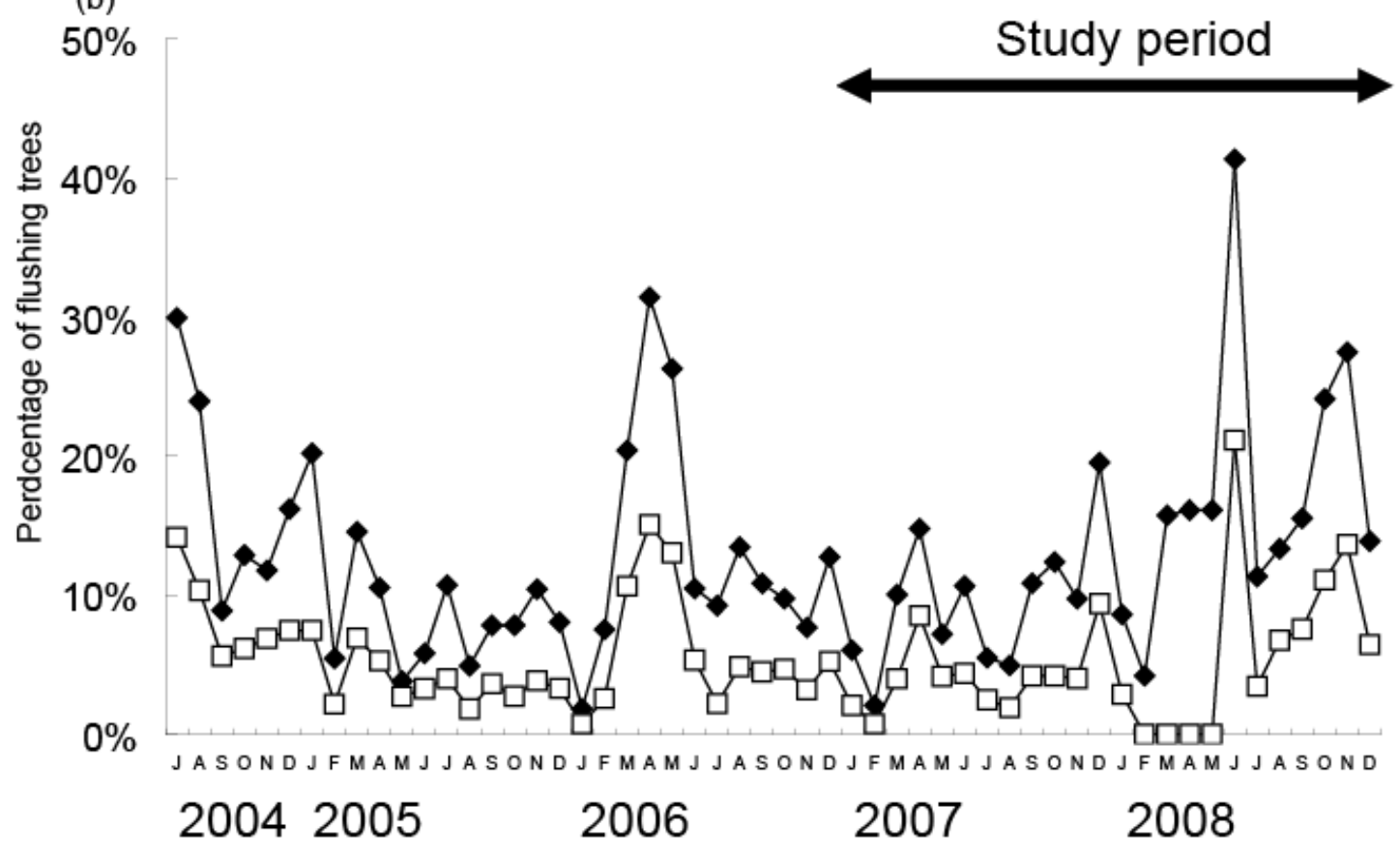

Fig. 2 
Diet of red leaf monkey Hanya and Bernard

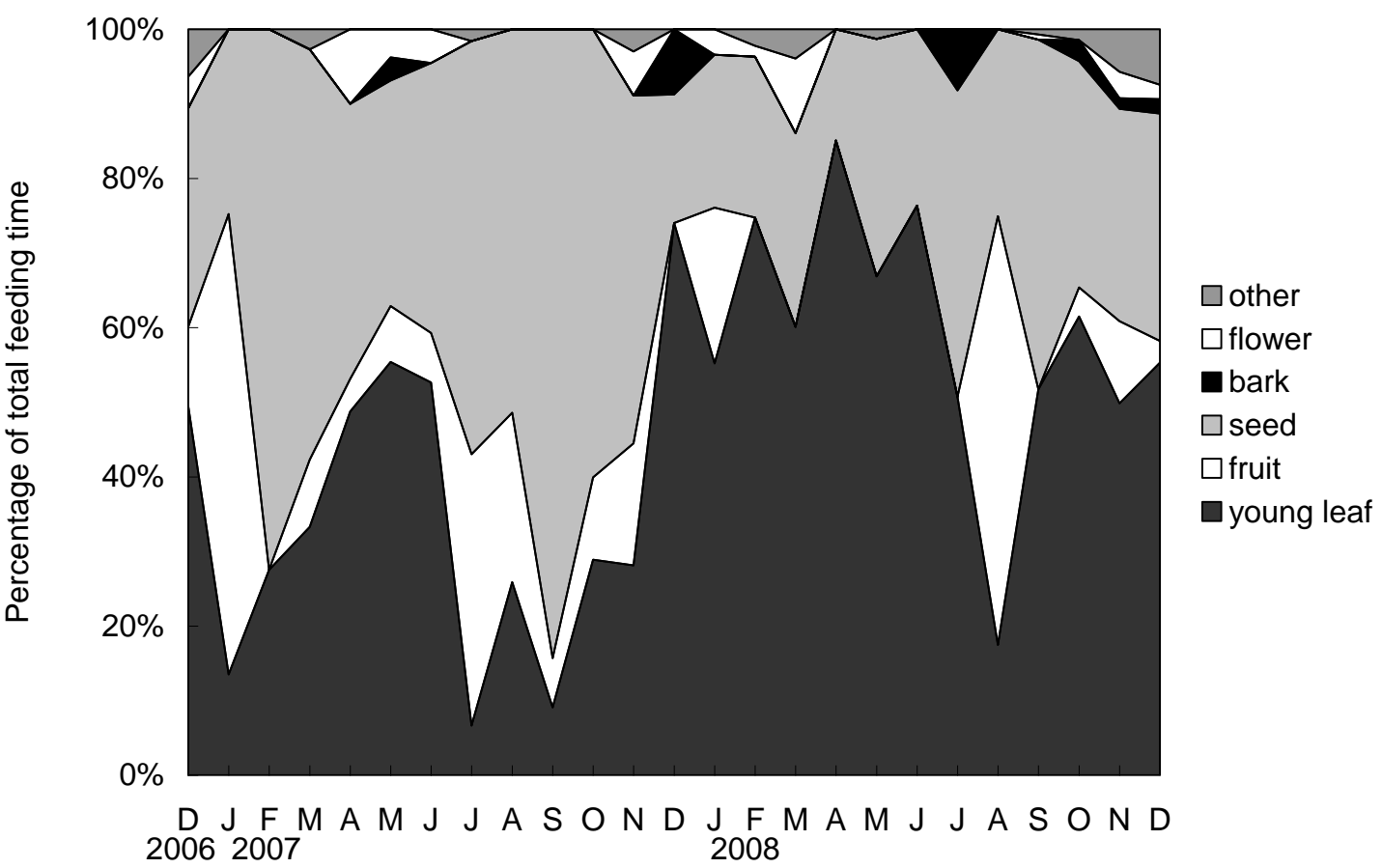

568 Fig. 3

569 
(a)

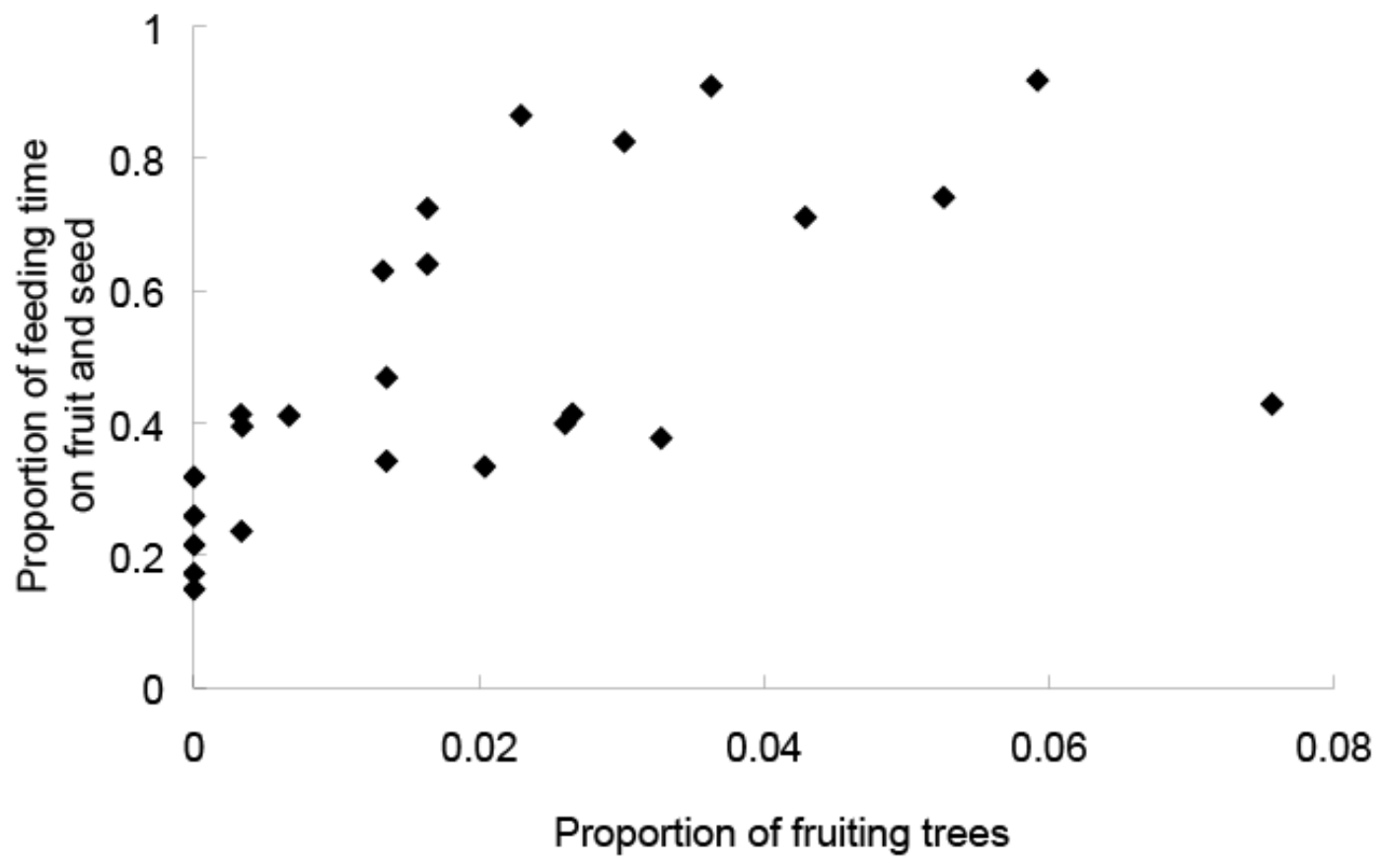

(b)

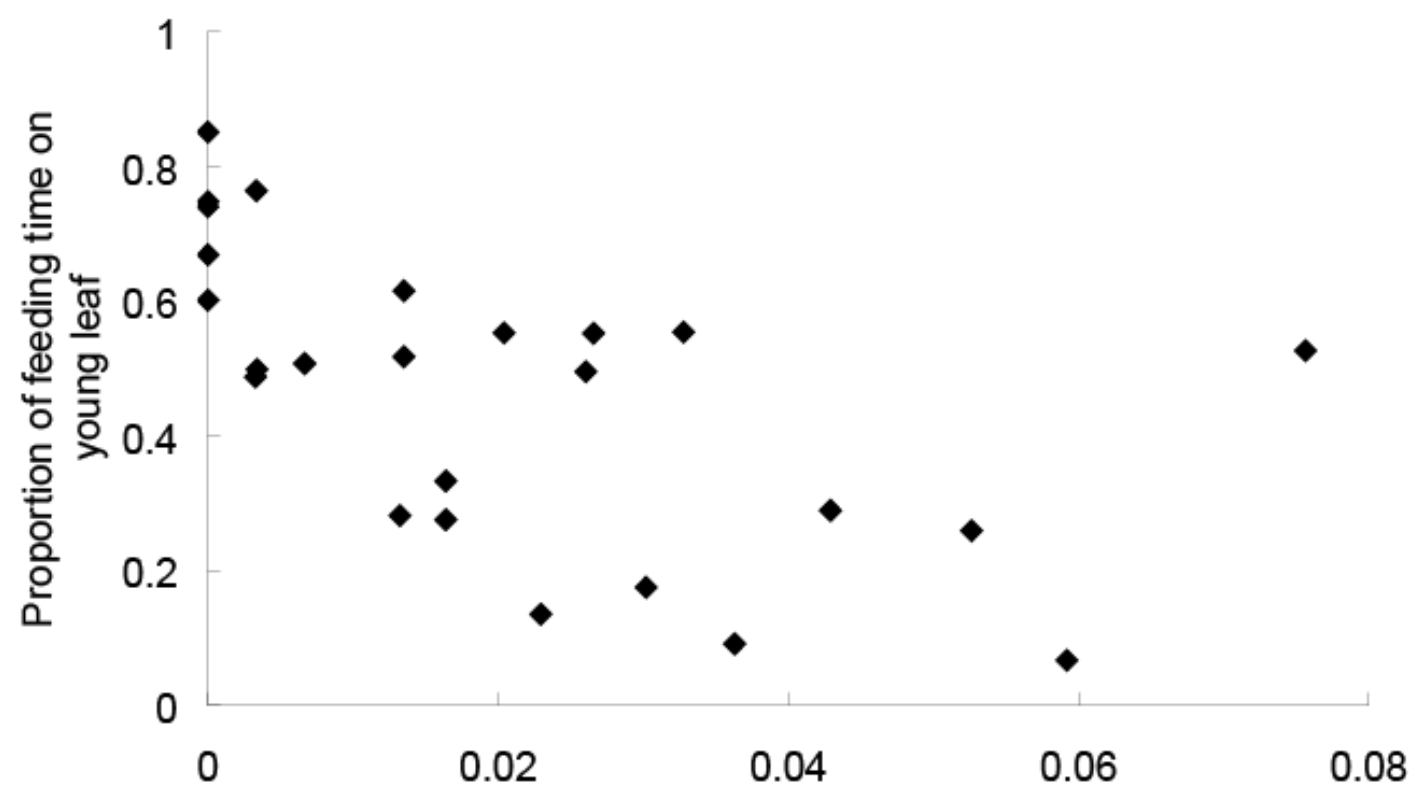

571 Fig. 4 
(a)

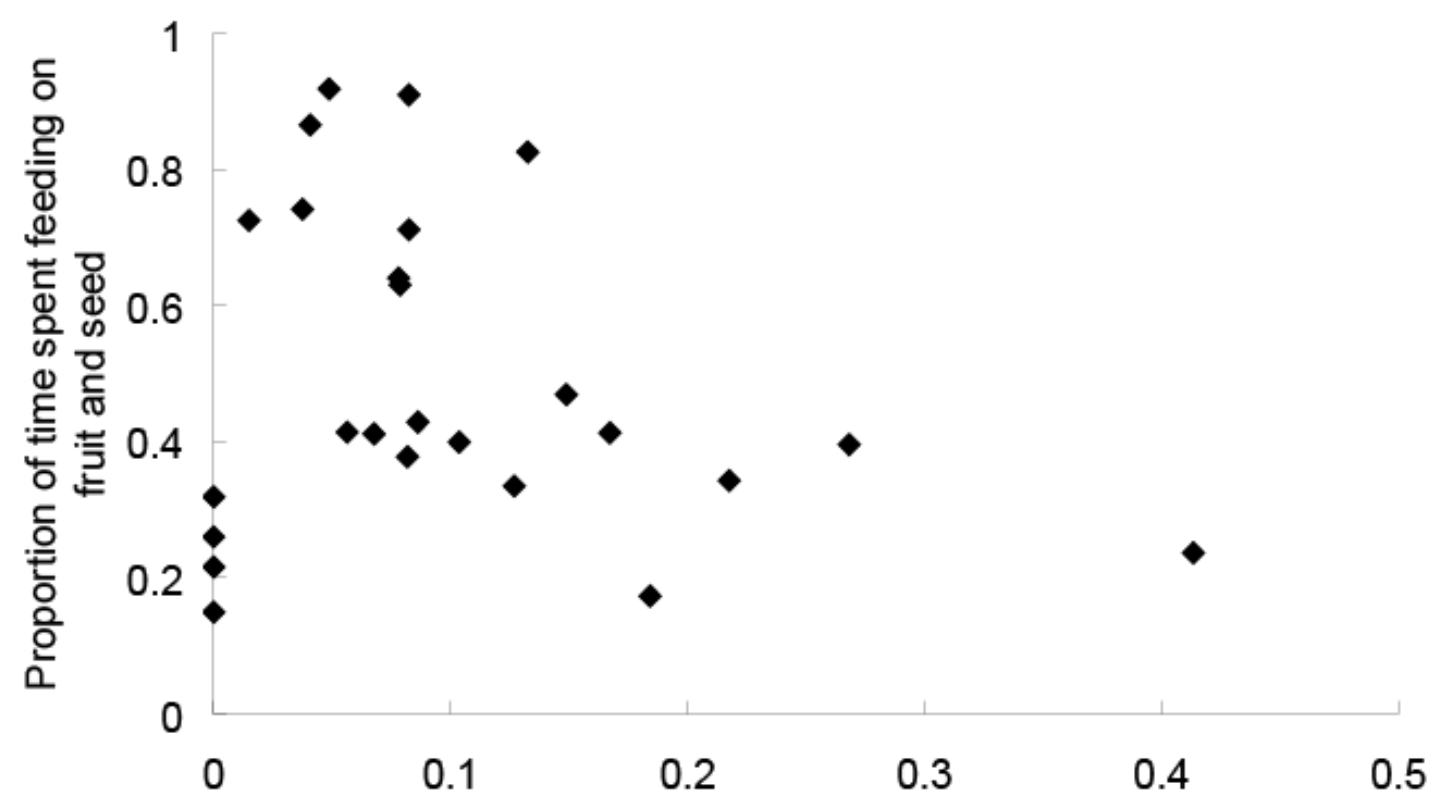

(b)

Proportion of flushing trees

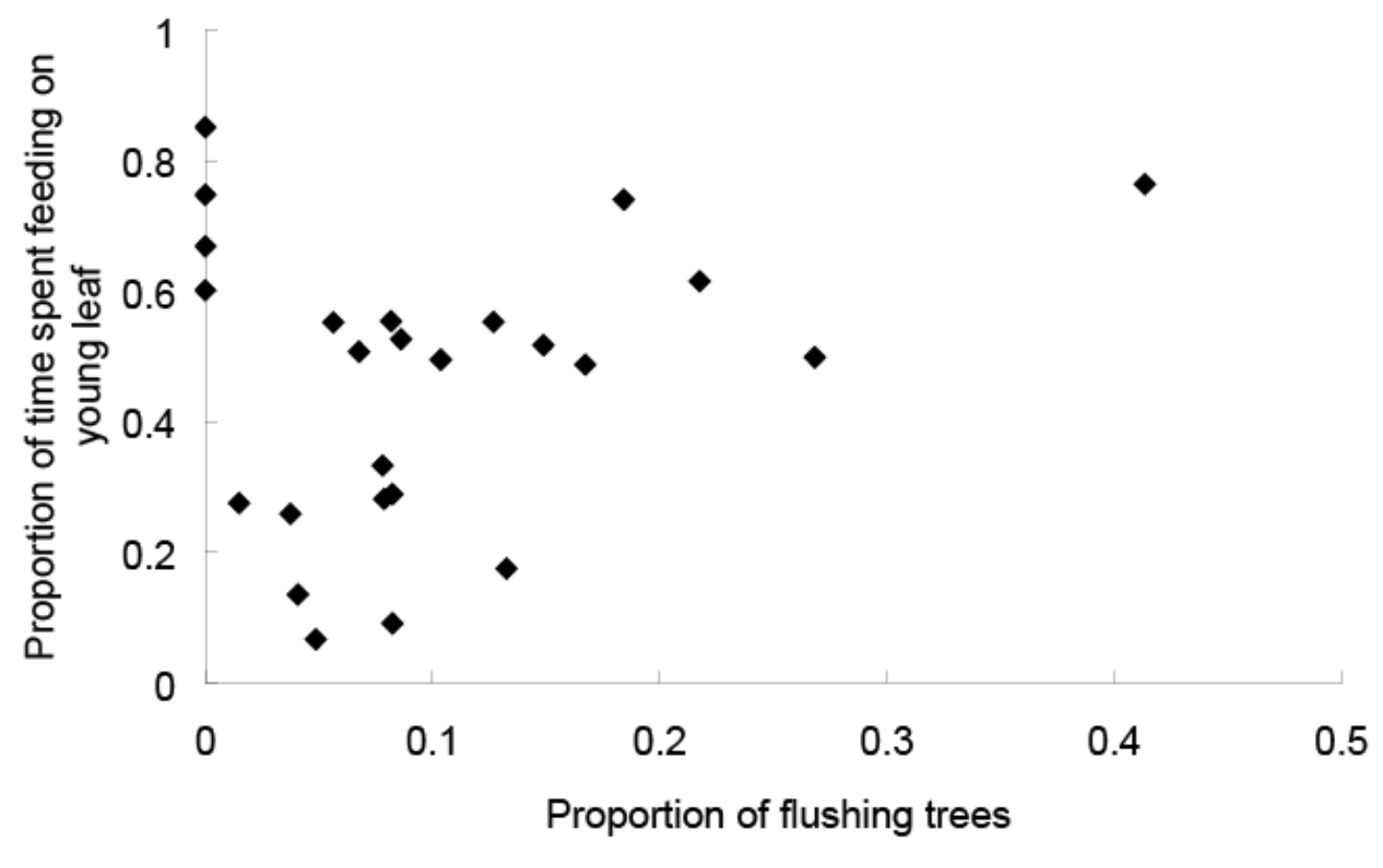

$574 \quad$ Fig. 5

575 
(a) NDF

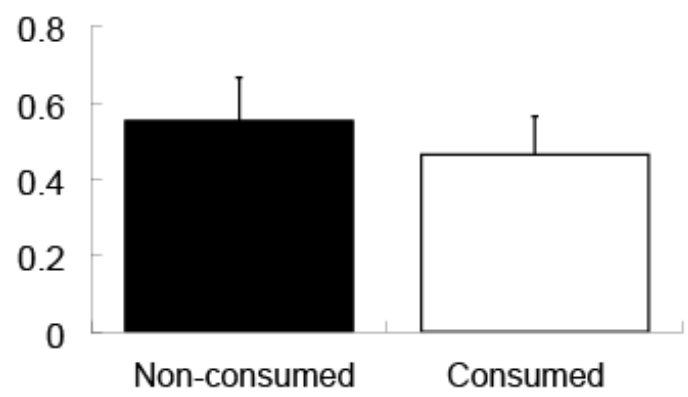

(c) Crude ash

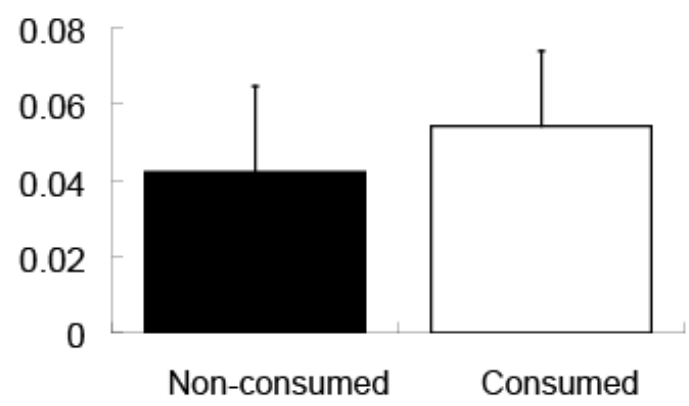

(e) Abundance

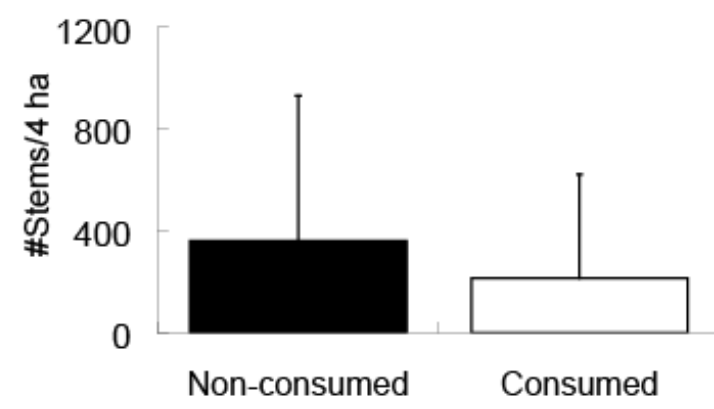

(b) Crude Protein

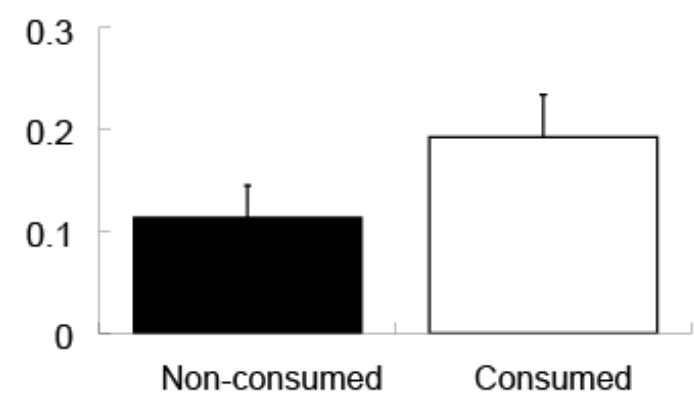

(d) Crude lipid

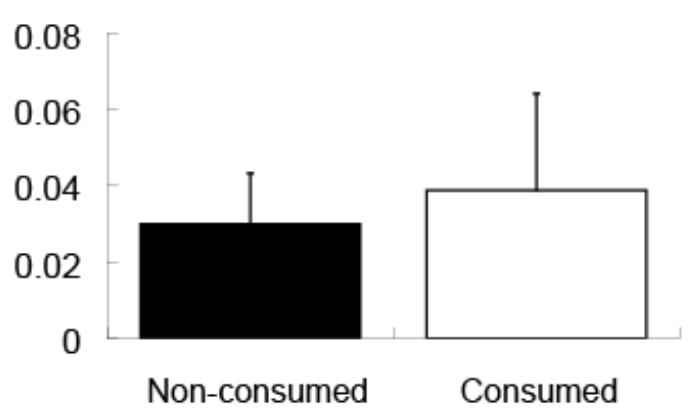

576

577 Fig. 6 